\title{
The Economic Paradigms Need to Be Updated
}

\author{
Jaroslav Daňhel - Eva Ducháčková - Jarmila Radová*
}

\begin{abstract}
:
This contribution deals with the current problems of the stagnating European economy: a high level of debt, political instability and a lower level of ethics. The growth of the income gap in society is viewed as one of the most pressing problems. Reference is made to the ineffectiveness of traditional fiscal and monetary policy, the problematic nature of solutions based on new tools, such as quantitative easing, and the low level of the effectiveness of implemented regulatory projects, which reduce the efficiency of regulated business. In a quest for new approaches to correcting economic paradigms, the authors recommend greater anticipation of empirical and behavioural approaches, or, possibly, even a return to the beginning - ie. to the ideas of the free market.
\end{abstract}

Key words: Economic paradigms; State regulation; Behavioural approaches.

JEL classification: A11, B41, D69, D74, G02, G22.

\section{Introduction}

This paragraph should contain literature review or review of conducted research.

In the current globalized world of the last decade, the characteristic movement of the real economy in Europe has been in the lower amplitudes of the economic cycle and has been complicated by the low effectiveness of the tools of fiscal and monetary policy and instability on the financial markets, which, in relation to the real economy, display features of autonomy and virtuality. The exchange rates of the euro, rouble or Czech crown display exceptional volatility, while the yields from financial instruments are at a historic minimum. These phenomena are the result of the stagnation of the European economy, a high level of indebtedness and an inability to solve effectively escalating political problems, such as military conflicts, terrorism, mass migration, economic sanctions etc. The aim of this

prof. Ing. Jaroslav Daňhel, CSc.; University of Economics, Prague, Faculty of Finance and Accounting, Department of Banking and Insurance, Winston Churchilla Square 4, 13067 Prague 3, Czech Republic, <danhel@vse.cz>.

prof. Ing. Eva Ducháčková, CSc.; University of Economics, Prague, Faculty of Finance and Accounting, Department of Banking and Insurance, Winston Churchilla Square 4, 13067 Prague 3, Czech Republic, <duchack@vse.cz>.

doc . RNDr. Jarmila Radová, Ph.D.; University of Economics, Prague, Faculty of Finance and Accounting, Department of Banking and Insurance, Winston Churchilla Square 4, 13067 Prague 3, Czech Republic, <radova@vse.cz>.

This article is processed with the contribution funds of constitutional support to long-term conceptual development of research at the Faculty of Finance and Accounting of the University of Economics Prague IP 100040 and GACR 15-00036S. 
contribution is to draw attention to some topical aspects of the problem of the determination of the current complex world from the point of view of possible ways to change the economic paradigms, especially the theory of the rational choice of homo oeconomicus.

\section{The Economics Paradigm}

At the theoretical level in this entirely new, more complicated environment, the economic paradigms which have hitherto applied are failing. As a result of the attempts to solve the financial crisis and the subsequent therapy, there is, in the various economies, a surplus of liquidity, which distorts the relationship between savings and investments and inhibits real economic growth. The traditional instrument of monetary policy is replaced by the controversial tool of quantitative easing, which increases the surplus of money even more. In the current escalating discussion about the effectiveness of QE, which central bankers, above all, regard as almost the only driver of economic growth, a significant section of expert opinion sees that tool as the possible source of a future crisis. The destructive influence of moral hazard and negative selection are becoming even stronger. Economic instability and a low level of ethics will then create the ideological space for stronger regulation in the spirit of Friedman' $s$ idea that freedom is a defensible goal only for responsible individuals (Friedman, 1991). In an environment in which there are reduced possibilities to use as a cure an instrument based on well-grounded conservative economic forecasting, a fear of chaos and being unable to control the complexity of global conditions leads politicians to intervene in the economy even more in an unsystematic, discretionary way and, subsequently, to extend regulation.

The general perplexity among experts and theoreticians stems from the fact that they are unprepared to face a sea change in the economic environment. The economic world is not experiencing a normal cyclical recession or crisis, but rather a long-term transformation and considerable metamorphosis. At the theoretical level, this process requires a fundamental change in the methodological approach to studying global economic conditions, humility in the face of the unpredictable, which is a crucial factor in politico-economic events, and respect for human beings as agents who have to make multiple-criteria decisions (Daňhel, 2015).

Current economic science evidently does not possess the theoretical instruments needed to encompass cognitively the complexity of a complicated global economy with significant elements of randomness. The preceding period of mass overconsumption in the core world economies, including the European ones, which caused an imbalance on such a scale that only a massive financial and economic crisis was able to correct it, was underpinned by the ideas of the welfare state, which give priority to short-term goals in the spirit of Keynes's quip that "in the 
long run we are all dead". Getting into debt was seen as more or less positive, an attitude that led to the crisis in public finances associated with an over-bloated welfare state. In the case of the EU this was exacerbated by an over-costly attempt to impose central control with considerable elements of bureaucracy. The Egyptologist M. Bárta believes, in this respect, that our system is becoming so complicated that it no longer has the necessary energy to keep itself running and therefore, in a historical analogy, it is in danger of collapse, which according to his concept means a loss of complexity (Bárta, Tureček, 2013).

\section{Regulatory Intervention}

The negative economic phenomena of the current globalized world are increasingly reflected at the political level. In the absence of appropriate recommendations based on economic theory, the bureaucratic machinery is attempting to promote more intervention by the state administration in the life of society, especially in the economic field. The absence of clear theoretical conceptions for today's complicated economic world clears the ground for improvising politicians who prefer short-term, pragmatic and therefore often unprincipled solutions timed to fit the electoral cycle (Daňhel, Ducháčková, Radová, 2010). There are currently many urgent problems to which neither leftwing nor right-wing politicians have a conceptually based solution. The most urgent is the growing income gap, which, together with consolidation, is causing social unrest, radicalizing a section of the political spectrum, and, to a certain extent, calling into question the democratic model of society itself. In this environment, which includes the already mentioned increase in negative choice and moral hazard, the previous positive development trends and the ideas of international and inter-sectorial integration are being eroded, and politicians are intervening even more in the economy in an unsystematic and discretionary way followed by extended regulation. Manifestations of regulatory intervention often take the form of legal norms and frequently, in some respects, go against the interests of business itself. These norms include inappropriate consumer protection measures, antidiscrimination measures in the insurance business etc. A practically insoluble contradiction then arises; regulatory measures implemented in the interest of the clients' security go beyond the bounds of reason and make financial services more expensive for the clients and less effective, which is the direct opposite of what they were meant to achieve (Daňhel, Ducháčková, Radová, 2013).

Current feeling among economic experts is reflected by the enthusiastic reception given at the end of last year to the worldwide bestseller by French economic Thomas Piketty "Capital in the twenty-first century" (Piketty, 2014). This book is considered to be the most significant work on an economic topic published in 
2014. The subject of the book is highly topical; it deals with the growing gap in income and wealth between people in selected economies in the last two hundred years. The long-term tendency for the wealth gap between rich and poor to widen has, in the last decade, been catalysed by the fatigue caused by a relatively long period of crisis and the continuation of an intensified competitive struggle including growing income inequality. This leads to an erosion of social cohesion, radicalizes part of the political spectrum and, to a certain extent, calls into question the democratic social model itself. Unless we are supporters of Piketty's extreme left-wing solution of highly progressive taxation (he often quotes Marx in his writings), then we must conclude that at the theoretical level there is no feasible solution to the problem of extreme income polarization.

\section{Greater Formalisation and Mathematisation}

Behavioural economists explain the subjective cause of the discrepancy using the principle of relative thinking (Ariely, 2009). In general, this tool helps in decisionmaking connected with income inequality, but it also, of course, causes a considerable negative impact, which can be seen in the following example: In 1976, a company director in the USA was paid, on average, 36 times as much as the average manual worker. By 1993 that ratio had reached 131:1. In that year, the American stock market regulators made it compulsory to publish directors' salaries, supposing that transparency would force the members of supervisory boards to reject exorbitantly inflated salaries. However, the complete opposite happened; directors started to compare their salaries, and those who earned less asked for more. The result was a further increase in the income gap. At the start of the decade the ratio had already grown to $369: 1$. According to behavioural economists, the solution lies at the ethical level: escaping the vicious circle of endless comparisons would, to some extent, be a remedy.

Part of the reason for the current lack of theoretical support, which would positively anticipate elements of the current negative development, lies in the fact that, in recent decades, theory has undergone a significant shift towards the greater formalization and mathematiation of economic science in an attempt to achieve greater rigour (maximisation or optimisation) and thereby more effective normative forecasting. The mathematising economists demanded of mathematics, a non-dialectic scientific discipline, a role in the social sciences which was contrary to its very nature.

This inappropriate emphasis on an excessive formalisation of the economy and intensive implementation of mathematical approaches, especially in the models of market regulation, with the aim of moderating volatility and achieving greater market stability, has stemmed, in the last two decades, from the concept of a "risk 
based approach" based on the thesis that it is possible to control the significant influence that randomness has on global economic conditions. The appropriate weapon was, supposedly, a robust database of historical data and a broad portfolio of sophisticated models. The hectic current state of the global economy is ample proof of the ineffectiveness of that type of "exact" approach to controlling, or even eliminating risk. A "safeguard" against the uncertainty and instability of global economic conditions simply does not exist. Time and again, the truth and validity of the basic methodological ambivalence about the unpredictability of the external world are confirmed, and, consequently, also the very limited human ability to make predictions as well as the truth of the basic methodological contradiction, which resembles an axiom: How can the future be made the object of scientific research when, as an object, it does not yet exist? Today's extremely complicated yet globalised world is characterised by highly improbable, unpredictable events of all kinds, with which formalised mathematical models, due to their low probability, cannot work and are, therefore, unable to calculate their consequences. The general difficulties prognostics have in this respect are well documented by the fact that because the results of prognostic modelling issued by respected institutions do not take into account randomness and do not sufficiently consider the volatility of economic phenomena, they are in sharp conflict with later reality. Economic development is, indeed, relative easy to predict, as long as it progresses in a standard way. However, as soon an unexpected event occurs, any correct prognosis is something of a one-off chance which is unlikely to be repeated (Mlčoch, 2010).

Nevertheless, we should be as well-prepared mentally as possible for the consequences of "unfettered" randomness. This is clearly better achieved by adopting the second, "softer", but nevertheless increasingly widespread approach to the tools of economic science. It is the approach represented by the heuristic and empirical economists, who, unlike the followers of classical theory, start from the basic fact that global economic conditions are by nature unpredictable, and that the social sciences, markets, politics and the whole of society are fundamentally unpredictable too.

According to the softer, empirical, cognitively psychological and heuristic approaches, people are viewed as multiple-criteria decision-makers who emphasise subjective viewpoints, including the ethical framework of economic interaction or even emotions, and who, in reality, base their decisions on factors other than the criteria of rational choice or maximum utility. These realities are better understood and experimentally proved by scientists who focus on researching situations in which people are not endowed with thinking based exclusively on a rational concept of probability and the optimal behaviour that 
stems from it, in conditions in which the result of their decision is strongly influenced by their ignorance of the impact of random influences.

In this context, we see the acute need for a discussion of the pressing economic problems of our time and of their methodological-philosophical basis at an appropriate specialist level, combined with an attempt to answer the question, why there is a lack of relevant theoretical support dealing with current economic events. In this respect we see the considerable inertia in the thinking of, so far, a majority of the expert community as an unpleasant consequence of the shift of economic theory in recent decades towards greater formalisation and mathematisation. A vivid example of this is the fact that respected specialist economics journals, including Czech and Slovak ones, openly prefer to publish the contributions of mathematising economists; the specialist level of the articles is judged by the number of formulae, tables and graphs they contain. On the other hand, contributions based only on empiricism and soft approaches, regardless of their cognitive value, evoke feelings of contempt among the editors of the respected journals with their "fixed" way of thinking. Soft, empirical patterns of thinking are viewed by them with reserve, and often biased indignation (Taleb, 2010). The mental inertia of the expert elite currently forms one of the barriers to finding new economic paradigms.

Judging by the current global politico-economic conditions it is increasingly clear that the fundamental problem is one of cognition. Discussion should be cleansed of bias and, in a spirit of democracy, allow a greater range of opinions. A general characteristic of a theory is that, even when it is accepted by the majority, its implementation in practice is always delayed. To a large extent, this is due to the already mentioned mental inertia of the expert elite. The thinking of theoreticians and researchers continues to be dominated by ideas of increasing the formalisation of economic science in order to achieve effective, normative forecasting in economic policy, despite the obvious lack of success of that doctrine.

\section{Results and Discussion}

One of the most pressing tasks facing theoretical economics in this respect is to strengthen, or reformulate, their methodological-philosophical basis of economic categories and to give them back a greater ethical dimension. Without a mental transformation of the attitude towards cognition of the global economic conditions with greater respect for the soft approaches, especially the positions taken by behavioural economists and empiricists, and humility in the face of randomness, which is a major factor in politico-economic events, it will be very difficult to find new paradigms. In this quote, Mlčoch 2010 follows on from the work of the mathematician Bašta, who, in the 1960s, formulated the concept of an internal 
model of the world of a decision-maker which was, to a large extent, in line with the principles of behavioural economics and the conclusions of the work of professors Kahneman and Tverský (1979), and who criticized the theory of expected utility and, therefore, the rigorous rationality of homo oeconomicus from the point of view of the empirical research of cognitive psychology.

In the recent decades marked by an increase in globalization, complexity and, often, the virtual nature of economic interactions, the liberal concept of allowing spontaneous market activity and not intervening in the workings of the free market has been regarded as a historical anachronism completely unsuited to the current economic world. In the meantime, we have undergone a severe financial and economic crisis and are at a loss how to act in the current post-crisis period. Experts on the collapse of civilizations warn that our society clearly displays the signs of impending collapse (Teplý, 2015). The logical option is, therefore, a return to the roots that offer simplification; a return to the free market, and a reduction in those well-meant, but evidently not very successful state interventions.

\section{Conclusion}

The inability to master the complexity and compression in both time and space of the phenomena of today's complex globalized world creates a whole new economic environment, has a significant impact on the state of the global economy and is becoming an urgent challenge for the social sciences, in particular in their search for new economic paradigms. One of the most pressing questions in this regard is the level of determinism in the world today and the role of randomness in the life of both society and individuals. The idea that economic science can achieve greater rigour and normative prediction through greater formalisation and mathematisation, an idea that has been widespread for at least the last two decades, increasingly looks like a dead end. More and more people are being won over by representatives of the open, soft scientific disciplines, which can better anticipate the consequences of randomness on global economic conditions and better elucidate the behaviour of people and economic subjects in decision-making problems in uncertain conditions. In this context, we believe that it is important that most economic problems should have the parameters not of decision-making problems in risk situations where the probabilities of the occurrence of random quantities are known in advance, but of decision-making problems with uncertainty and indefiniteness.

The dilemma of anticipating randomness in economic problems can be seen clearly in the problem which the insurance business is currently trying to solve, 
when commercial insurance is a historically tried and tested tool for financially eliminating the consequences of randomness.

\section{References}

Ariely, D., 2009. Jak drahé je zdarma? Práh, Praha.

Bárta, M., Tureček, T., 2013. Kolaps neznamená konec, Vyšehrad, Praha.

Daňhel, J., 2015. Knihy prokazující lidskou iracionalitu při ekonomickém rozhodování a vady teorie racionální volby. Politická ekonomie 6, 801-808. ISSN 0032-3233.

Daňhel, J., Ducháčková, E., Radová, J., 2010. Theoretical Economics Faces a Serious Challenge. European Financial and Accounting Journal 3-4, 7-15. ISSN 1802-2197.

Daňhel, J., Ducháčková, E., Radová, J., 2013. Economic Theory Needs a New View of the Phenomenon of Randomness. Journal of Emerging Trends in Economics and Management Sciences 5, 460-466. ISSN 2141-7024.

Friedman, M., 1991. Svoboda volby. Liberální institut, Praha.

Kahneman, D., Tversky, A., 1979. Prospect Theory: An analysis of decision under risk, Econometrica 47.

Mlčoch, L., 2010. Sociální ekonomika a sociální chování: nástin cest k rozšířenému paradigmatu ekonomie, Konference 20 let IES, Praha.

Piketty, T., 2014. Capital in the Twenty - First Century, Belknap Press.

Taleb, N. N., 2010. Černá labut', Praha - Litomyšl, ISBN 978-80-7432-128-3.

Teplý, P., 2015. A macroeconomic view on investments and innovations - a fairy tale about 3 myths. Development and innovations of financial products, International conference at Faculty of Finance and Accounting, University of Economics, 2015, Prague. 